\title{
Influence of Quality Improvement Activities and Direct Selling Through Mediated Partnership Model on Supply Chain, Farm-Gate Price and Indonesian Households Specialty Coffee Farmers' Income
}

\author{
Diany Faila Sophia Hartatri $\left.{ }^{*}\right)$ \\ ${ }^{1}$ Indonesian Coffee and Cocoa Research Institute, J1. PB. Sudirman 90, Jember Indonesia \\ ${ }^{*}$ Corresponding author: il_three@yahoo.com \\ Received: 16 November 2015 / accepted: 21 January 2016
}

\begin{abstract}
Low farm-gate price of agricultural commodities is commonly caused by low quality and complicated value chain. Quality improvement and direct selling through mediated partnership model (Motramed) are conducted to increase farm-gate price and bargaining power of smallholder farmers. In Indonesia, Motramed has been applied in several coffee producing regions, such as Flores, Bali and East Java. This research aimed to study the influence of quality improvement and direct selling activities through Motramed on market chain, farm-gate price and household farmers' income. This research was conducted in Kintamani, Bali, in 2013. This research also used farm-gate price data in several specialty coffee producing regions, including Flores (Bajawa and Ruteng), Kintamani and East Java that collected during 2010 and 2011. Both quantitative and qualitative research methods were incorporated to explore and analyse the data. Household farmer survey, semistructured interview with coffee stakeholders including farmers, collectors, exporters, government officials and NGOs; and field observation were used for collecting the data. The research showed that quality improvement activity in farm level and direct selling through Motramed had shorten the market chain, increased farm-gate price and increased household farmers' income.
\end{abstract}

Keywords: specialty coffee, quality improvement, direct selling, income, Motramed

\section{INTRODUCTION}

Coffee has been traded in the world market for centuries and has important role in human life. Culture of drinking coffee has started around hundreds years ago in Ethiopia and Yemen, and then spread to Italy, India, Europe, Indonesia, the United States and other countries. Nowdays, coffee is a special drink that has major influences in most cultures around the world. According Panhuysen \& Joost (2014), in 2012, total number of world's consumption of coffee reached up to 142 million bags which means that coffee is one of the most important agricultural commodities for both coffee producing countries, mostly developing countries and consuming countries.

According to Neilson (2007), the end of International Coffee Agreements (ICAs) in 1989 had impacted on both producers and consumers of coffee countries, such as significant decrease of coffee price. As the consequence, this affected significantly the living of coffee farmers who were mostly in developing countries, and significant development of the world's specialty coffee 
market. Furthermore, it increases product differentiation, such as single origin coffee and coffee-certified marketing (for example Organic, Rainforest Alliance and Fair Trade). Today, the specialty coffee industry becomes the most prospective and significant industry in the world's market of coffee (Ponte, 2002). Since recent five years, the economy of world coffee market has been significantly changed due to development of coffee products, application of certification system, and labeling systems of coffee products. Thus, it has increased the chances of coffee producers to get involved and produce more certified coffee.

In 2006, total production of Arabica and Robusta coffee in Indonesia was the third largest world coffee producer reaching up to 680,000 tons per year (Ditjenbun, 2007). According to AICE (2007), the export of Indonesian Arabica coffee was about $33 \%$ of the total export value of Indonesia and according to Ottaway (2007), coffee contributed about $0.6 \%$ of national income or approximately $17 \%$ of the total revenue of all exported agricultural products in Indonesia. For Indonesia, this commodity has an important role for national revenue and for about two million domestic farmers in some coffee-producing areas, such as Aceh, North Sumatera, East Java, South Sulawesi and East Nusa Tenggara (Ditjenbun, 2012).

Global demand for high-quality coffee or specialty coffee has increased (Marsh \& Neilson, 2007a; Marsh \& Neilson, 2007b). This increase may give larger opportunity for coffee farmers in Indonesia to get involved in the global trade of coffee. However, according to Neilson (2008), Indonesian coffee is mostly produced by household coffee farmers who have several limitations, such as difficulty in accessing knowledge and extension services technologies related to coffee and information related to global trade. Thus, these limitations have caused Indonesian coffee farmers find difficulties in producing high-quality of coffee as expected by the consumers. Further, this has led Indonesian farmers generate lower income from specialty coffee global market.

In order to overcome the problems faced by farmers, there have been many various interventions recently conducted by Governments of Indonesia, international agencies such as USAID, GTZ, DFID, and private sectors. The stakeholders generally facilitate the coffee farmers to improve coffee quality which is an effort to increase competitiveness and, eventualy to increase prices at farm level.

Improving the ability of producers in order to improve the competitiveness in global market is the concept of upgrading in value added. Upgrading has an important role, especially for producers in developing countries to face the competition in global market where the impact of upgrading activity for the producers in general is quite significant.

Humphrey \& Schmitz (2002) classified four types of upgrading, namely in process, product, function and intersectoral aspects. Porter (1990); Kaplinsky (2000) and Humphrey \& Schmitz (2002) argued that improving the quality and efficiency of production activities is upgrading activity that provides the most excellent response in an effort to improve competitiveness of the product. However, due to the implementation of upgrading which requires more advanced technologies and skills, household farmers in developing countries need the support from other actors such as governments, NGOs and the private sectors in the implementation of upgrading.

Improving the quality of coffee produced by coffee farmers in Indonesia as an effort to increase the value added is the most commonly applied action since the last ten years. This is because the majority of Indonesian coffee 
known as low-quality coffee (random). Supporting quality improvement activities require skills and additional material. Thus, implementation of upgrading at the household scale farmers in Indonesia requires the role of other stakeholders in facing the difficulties.

Upgrading activities that have been performed in the specialty coffee sector through improving the quality of human resources had been facilitated by Government in cooperation with Indonesian Coffee and Cocoa Research Institute (ICCRI). Quality improvement activities that have been carried out by the coffee farmers were conducted in parallel with business partnership program known as Partnership Mediated Model (Model Kemitraan Bermediasi/Motramed). This program was initiated by ICCRI in 2001. The implementation of this program involved both farmers and buyers either exporters or the industry as farmer partners, while ICCRI served as mediator for both sides. For the first time, these activities were carried out in Kintamani, Bali and had been replicated in several other regions of coffee producers in Indonesia, such as Flores and East Java (Situbondo and Bondowoso). Although Motramed has been applied in some coffee-producing areas, research on the impact on the Motramed farmers is still very limited. Therefore, this study aimed to determine the effect Motramed on the supply chain, as the farmgate prices of farmers' income.

\section{MATERIALS AND METHODS}

This study combined quantitative and qualitative methods for data collection and data analysis. Method for data collection to determine the supply chain and the price of coffee was done through a semi-structured interview method with some coffee stakeholders, such as coffee farmers, coffee collectors, local traders and exporters in several coffee- producing regions, in Kintamani, Flores (Bajawa and Ruteng) and East Java. The data collection was conducted in July-September 2013. In addition, the author also used data collected in 2010 and 2011 as it was intended to compare the prices of coffee in that years.

In addition, coffee farmer household survey was conducted to collect data in terms of revenues of coffee farmers conducted in July-August 2013 in the village of Belantih and Ulian, Kintamani. There were 100 farmers chosen for each village in this study as respondents. Of the chosen respondents, 50 farmers in the village were farmers engaged in quality improvement activities and direct sellings, while the other 50 farmers were common farmers who were not involved in the quality improvement activities.

In addition, this study also collected data through field observation which was conducted to support other data collection and were used to support analysis of the results. In quantitative terms, the data were analyzed using t-test analysis using SPSS 17.0. This analysis was done by comparing the value of $t$ in both groups of farmers, namely the group of farmers involved and not involved in Motramed.

\section{RESULTS AND DISCUSSION}

The main purpose of the activity of coffee quality improvement (upgrading) and direct sellings through Motramed is to improve the competitiveness of products produced by coffee farmers in global market. Thus, improving the quality of coffee and the short supply chain of coffee may increase the price of coffee at farm level.

Nowdays, majority of coffee farmers produced unsorted and ungraded dry coffee beans which means that they received relatively low coffee prices. Through Motramed, ICCRI encouraged the coffee farmers to produce 


\begin{tabular}{lcccc}
\hline Motramed involvement & Average coffee bean price $(\mathrm{Rp} / \mathrm{kg})$ & T calc. & T table & Sig.(2 tailed) \\
\hline No & 19,187 & 4.590 & 1.98 & 0.000 \\
Yes & 28,089 & & & \\
\hline
\end{tabular}

full-washed coffee and market the coffee beans to farmers group known as product processing unit (UPH) or farmer's mutual unit (FMU). Thus, according to the type of upgrading classification by Humphrey \& Schmitz (2002), the activities of quality improvement in the specialty coffee sector in Indonesia were grouped as product and functional types of upgrading. Neilson (2013) stated that product upgrading is done through improved product quality that may significantly contribute to the increase in domestic value added.

In addition to quality improvement, efforts to increase the price of coffee have also been done through direct sellings to coffee buyers, both exporters and industries either domestic on international. Through direct sellings, farmers' groups are expected to obtain a better coffee price.

\section{Effect on Coffee Supply Chain}

Coffee beans in Indonesia are generally distributed through three until four parties before reaching consumers. According to Supriatna \& Dradjat (2012), supply chain includes traditional marketing channels, where there are multiple parties involved, namely farmers as producers, coffee collectors (or sometimes as middlemen), wholesalers (in local market) and exporters. According to Azzaino \& Sudaryanto et al. cit. Supriatna \& Dradjat (2012), by engaging in traditional marketing channels, farmers tend to receive lower prices because traders will try to maximize their profits. Thus, farmers have lower chances for achieving welfare than the traders.

In Kintamani, Flores and East Java, for farmers not involved in Motramed they generally marketed their coffee to collectors (middlemen) in form of unsorted and ungraded coffee beans produced from coffee cherries that had different maturity level and dry processing method. Thus, the quality of the coffee product was low which did not match the demand for coffee in global market. The quality of coffee product influences the price received by the farmers. In addition, the complicated coffee supply chain also has affected on coffee prices.

With direct business partnerships between farmers (farmers' groups) with private sector, such as exporters and retailers, farmers have a greater opportunity to increase prices as well as their revenues. Sulistyani (2004) stated that partnership was the solution to improve the welfare of the farmers. In addition, there are many other advantages that can be obtained by the farmers through direct partnerships, such as gaining greater opportunities for access to the newest knowledge and technology related to coffee, especially post-harvest handling and quality control.

The results showed that the traditional supply chain of Kintamani coffee was relatively complex and there were more parties involved in the supply chains. While the supply chain partnership of coffee through Motramed was simpler, fewer traders involved in the supply chain. Thus, it can be concluded that the business partnership through Motramed had 
shortened the coffee supply chain (Figure 1). Processing and direct marketing activities in Motramed encourages coffee farmers to sell red coffee cherries to farmers' group (UPH). Next, farmers' group processed coffee through full-washed method to produce parchment coffee and dried coffee green beans. The coffee produced by the UPH were subsequently marketed directly to the exporters or retailers with the mediation assistance from ICCRI.
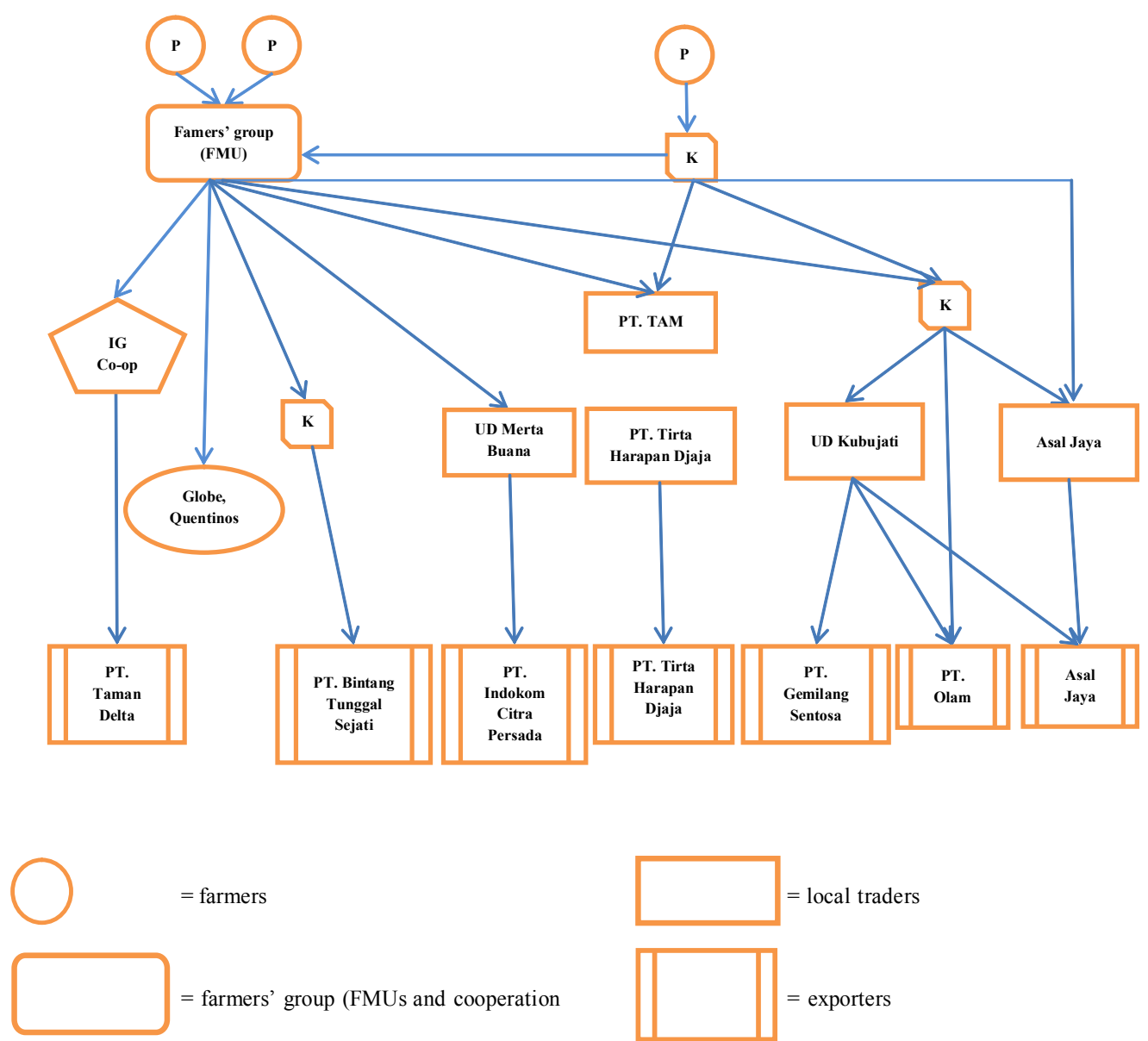

$=$ farmers

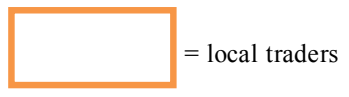

$=$ farmers' group (FMUs and cooperation
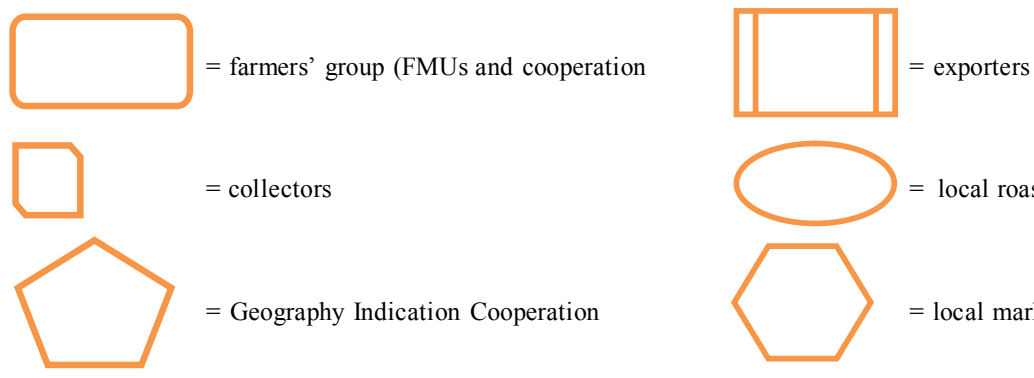

$=$ collectors

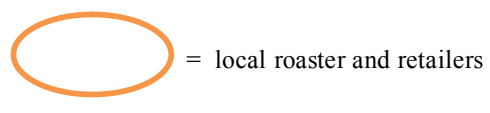

$=$ Geography Indication Cooperation

$=$ local market

Figure 1. Structure of coffee supply chain structure in Kintamani in 2012 


\section{Effect on Coffee Price}

Household coffee farmers in Indonesia included coffee farmers who generally sell coffee traditionaly, in which coffee farmers sell to collectors (middlemen) who make purchases in the local market or even directly visit to the farmers' houses or plantations. This traditional marketing model has reduced transportation costs. Furthermore, many collectors lend their money to farmers, and thus the collector has an important role in helping farmers' daily needs. However, farmers often must receive a rebate or high pay interest for the loans. Thus, coffee prices received by the farmers are often much lower than the market price.

To determine the effect of increasing the quality and price of coffee on the direct sellings, data collection has been conducted in three locations of specialty coffee producers, namely Flores (Bajawa and Ruteng), Kintamani and East Java.

The results showed that in these three locations, coffee prices received by UPH were higher than that of the local traders (Table 2). The high price in the UPH level is due to increased quality of coffee produced by the farmers (Mawardi et al., 2006). The high level of competition in both domestic and overseas buyers to high-quality coffee has also affected the price of the coffee. According Mawardi et al. (2006), improvement of coffee quality has upgraded cup taste of coffee. Further this has attracted exporters to buy coffee processed by the UPH. In addition, the system of direct sellings adapted by the UPH has also affected the increase of coffee prices received by the farmers.

Table 2. Farm-gate price from 2010 to 2012

\begin{tabular}{|c|c|c|c|c|c|c|c|}
\hline \multirow{3}{*}{ Locations } & \multirow{3}{*}{ Product forms } & \multicolumn{6}{|c|}{ Coffee beans price (IDR $/ \mathrm{kg}$ ) } \\
\hline & & \multicolumn{2}{|c|}{$\begin{array}{c}2010 \\
\text { (median) }\end{array}$} & \multicolumn{2}{|c|}{$\begin{array}{c}2011 \\
\text { (median) }\end{array}$} & \multicolumn{2}{|c|}{$\begin{array}{c}2012 \\
\text { (median) }\end{array}$} \\
\hline & & $\min$ & $\max$ & $\min$ & $\max$ & $\min$ & $\max$ \\
\hline \multicolumn{8}{|c|}{ Bajawa (Flores) } \\
\hline \multirow[t]{2}{*}{ UPH } & Red coffee & 24,000 & 27,000 & 31,200 & 39,000 & 21,000 & 33,000 \\
\hline & Dried HS & 29,500 & 29,500 & 51,000 & 66,000 & 45,000 & 45,000 \\
\hline Local traders & Coffee beans & 15,000 & 25,000 & 25,000 & 39,000 & 13,500 & 28,500 \\
\hline \multicolumn{8}{|c|}{ Ruteng (Flores) } \\
\hline UPH & Dried HS & 27,100 & 27,100 & 51,000 & 45,000 & 45,000 & \\
\hline \multirow[t]{2}{*}{ Local traders } & Coffee beans & 12,000 & 21,000 & 22,000 & 40,000 & 25,000 & 30,000 \\
\hline & & 21,900 & 24,000 & 15,000 & 37,500 & 42,600 & 42,600 \\
\hline \multicolumn{8}{|c|}{ Kintamani (Bali) } \\
\hline \multirow[t]{4}{*}{ UPH } & Red coffee & 30,000 & 33,000 & 36,000 & 40,000 & 27,000 & 39,000 \\
\hline & Dried HS & 31,000 & 40,000 & 51,600 & 54,000 & 22,800 & 45,000 \\
\hline & Wet HS & & & 43,230 & 49,500 & 31,350 & 38,940 \\
\hline & Coffee beans & & & & 65,000 & & \\
\hline Local traders & Coffee beans & 20,000 & 25,000 & 30,000 & 35,000 & 20,300 & 32,500 \\
\hline \multicolumn{8}{|l|}{ East Java } \\
\hline \multirow[t]{2}{*}{ UPH } & Red coffee & 19,200 & 24,000 & 19,200 & 37,200 & 27,000 & 39,000 \\
\hline & Wet HS & 19,500 & 19,500 & 23,100 & 44,500 & 26,400 & 39,600 \\
\hline Local traders & Coffee beans & 15,000 & 17,000 & 25,000 & 32,000 & 28,000 & 30,000 \\
\hline
\end{tabular}


The results from interview showed that the UPHs in Flores and East Java sold their products to exporters in Surabaya. While UPH in Kintamani had several buyers such as exporters located in Semarang and Surabaya, coffee roasters companies, and local retailers (including cafe), and coffee roasters company from Australia (Five Senses).

Table 2 also shows that the impact of the increase in largest added value of the coffee can be seen from the margin of the price differences in the UPH level and local traders in Flores. The greather impact of quality improvement occurred in areas that generally have low quality. Research conducted by Soemarno et al. (2009) showed that quality improvement in Flores had generated value added for the ratio of the output and input values were $17.8 \%$ to $22.4 \%$ or $21.6 \%$ to $28.9 \%$. While the price differences between the UPH and local traders in East Java were relatively low compared to the other two locations. This is because the UPH marketed the coffee in the form of wet coffee parchment, while two other locations marketed the coffee in the form of green beans coffee or dried parchment coffee. Thus, the sale of green beans coffee or dried coffee parchment had increased prices received by the UPHs. Hence, in general, the activities of quality improvement by performing full-washed coffee processing through Motramed may increase the price of coffee at the farm level.

\section{Effect on Coffee Farmers' Income}

Indonesian farmers are likely depend largely on agriculture and non-agriculture sectors to meet their daily needs. In agricultural sector, farmers commonly plant coffee through crop diversification system, where in the coffee plantation they also plant other crops, such as bananas, oranges and others. In addition to functioning as cover crops, the plants also contribute to the household economy of the coffee farmers. While in the non-agricultural sector, the coffee farmers also earn extra income from other sources, such as kiosks, drivers, construction workers and others.

To observe the effect of upgrading activities and direct sellings, survey to household coffee farmers in Kintamani was conducted. The survey was conducted on farmers who involved and not involved in Motramed. Based on the survey results, farmers who involved in the upgrading activities and direct sellings through the Motramed program obtained significant higher of total revenue than that of the farmers who were not involved in the upgrading activities and direct sellings (Table 3 ). However, the income of farmers from coffee in both groups of farmers did not show significant difference. This is because despite the high coffee prices, farmers did not only depend on coffee crops; therefore they did not provide maximum investment in their coffee plantations, which in turn may affect the production of their coffee. Thus, the farmers' household income from coffee

Table 3. Household income of coffee farmers involved and not involved in Motramed in Kintamani, 2012

\begin{tabular}{lccc}
\hline Indicators & $\begin{array}{c}\text { Farmers not involved } \\
\text { (IDR/year) }\end{array}$ & $\begin{array}{c}\text { Farmers involved } \\
\text { (IDR/year) }\end{array}$ & Significance \\
\hline Total revenue (average) & $41,580,400$ & $63,910,110$ & significant \\
Revenue from coffee (average) & $16,091,700$ & $25,304,242$ & not significant \\
Revenue from orange (average) & $14,474,948$ & $31,669,446$ & significant \\
Revenue from livestock (average) & $3,836,735$ & $6,390,000$ & not significant \\
Revenue from other aspect (non-farming) (average) & $5,593,200$ & $3,456,660$ & not significant \\
\hline
\end{tabular}


plantations did not differ significantly.

In addition, according to the results of interviews with farmers showed that since 2012 , the price of citrus as intercrops in the coffee plantation has increased significantly, while the price of coffee has decreased slightly. This has resulted in a decreased motivation of farmers to grow coffee. According to the observations in the field, since the last two years many coffee trees were cut down and replaced with citrus. Thus, it impacts on household income of coffee farmers in Kintamani in coffee plant sector.

\section{CONCLUSION}

Quality improvement activities as well as direct sellings of coffee to buyers that have been implemented in several coffeeproducing areas have managed to shorten the coffee supply chain, which in turn increasing the coffee prices received by the farmers, as well as total income of the households coffee farmers. Upgrading programs and direct sellings through Motramed program has managed to build a closer relationship between mutual farmer group (UPH) with coffee buyers (exporters and coffee industries), both from domestic and overseas. Thus, farmers' group now has a higher bargaining position in the coffee business. However, the implementation of the upgrading activities may face several challenges, such as the complexity of livelihood strategies of coffee farmers in Indonesia who are not only dependent on coffee plants. Accordingly, it is affecting the low investments made by farmers in coffee plantations.

\section{ACKNOWLEDGMENT}

Great gratitude is presented to ACIAR as the sponsor of this research. The author also would like to acknowledge Dr. Jeffrey
Neilson, Dr. Surip Mawardi and Dr. Yayoi Fujita Lagerqvist as members of researcher team.

\section{REFFERENCES}

AEKI (2007). Statistik Kopi 2005-2007. Jakarta, BPP AEKI Pusat.

Ditjenbun (2012a). Statistik Perkebunan Indonesia. Direktorat Jenderal Perkebunan. Jakarta.

Ditjenbun (2015). Statistik Perkebunan Indonesia. Kopi. Direktorat Jenderal Perkebunan Jakarta.

Humphrey, J. \& H. Schmitz (2002). How does insertion in global value chains affect upgrading in industrial clusters? Regional Studies, 36, 1017-1027.

Kaplinsky, R (2000). Globalisation and unequalisation: what can be learned from value chain analysis? The Journal of Development Studies, 37, 117-146.

Marsh, A. \& J. Neilson (2007a). Securing the Profitability of the Flores Coffee Industry. Australian Centre for International Agricultural Research. Canberra.

Marsh, A. \& J. Neilson (2007b). Securing the Profitability of the Toraja Coffee Industry. Australian Centre for International Agriculture Research. Canberra.

Mawardi, S.; I. Cahya; W. Aris; Sulistyowati \& Yusianto (2006). Model Kemitraan Bermediasi (Motramed) untuk pengembangan agribisnis kopi melalui perbaikan mutu dan system pemasaran di tingkat kelompok tani. Prosiding Symposium Kopi 2006. Pusat Penelitian Kopi dan Kakao Indonesia. Jember.

Neilson, J. (2007). Institutions, the governance of quality and on-farm value retention for Indonesian specialty coffee. Singapore Journal of Tropical Geography, 28, 188-204.

Neilson, J. (2008). Global private regulation and value-chain restructuring in Indonesian smallholder coffee systems. World 
Development, 36, 1607-1622.

Neilson, J. (2013). The value chain for Indonesian coffee in a green economy. Buletin RISTRI, 4, 183-198.

Ottaway, A. (2007). A Rapid Assessment of the Specialty Coffee Value Chain in Indonesia. The publication for review by the USAID. Jakarta.

Panhuysen, S. \& P. Joost (2014). Coffee Barometer 2014. Hivos, IUCN Nederland, Oxfam Nov ib, Solidaridad, WWF.

Ponte, S. (2002). The 'Latte Revolution'? Regulation, markets and consumption in the global coffee chain. World Development, 30, 1099-1122.

Porter, M. (1990). The Competitive Advantage of Nations. Macmillan, London.

Soemarno, D.; M. Surip; Maspur \& P. Henik (2009). Peningkatan nilai tambah pengolahan kopi Arabika metode basah menggunakan Model Kemitraan Bermediasi (Motramed) pada Unit Pengolahan Hasil di Kabupaten Ngada - NTT. Pelita Perkebunan, 25, 38-54.

Sulistyani, A.T. (2004). Kemitraan dan Model Pemberdayaan. Yogyakarta: Gava Media.

Supriatna, A. \& B. Drajat (2012). Pola Kemitraan dalam peningkatan efisiensi pemasaran kopi rakyat. Prosiding Seminar Nasional "Petani dan Pembangunan Pertanian”. Pusat Sosial Ekonomi dan Kebijakan Pertanian.

$* * 0 * *$ 